\title{
SIFAT ORGANOLEPTIK PERMEN JELLY MANGGA KUINI (Mangifera odorata Griff) DENGAN VARIASI KONSENTRASI SIRUP GLUKOSA DAN GELATIN
}

\author{
Organoleptic Properties of Kuini Mango (Mangifera Odorata Griff) Jelly Candy with \\ Different Concentration of Glucose Syrup and Gelatine
}

\author{
Putri A. A. U. Sachlan 1)*, Lucia C. Mandey ${ }^{2)}$, Tineke M. Langi ${ }^{2)}$ \\ ${ }^{1)}$ Mahasiswa Program Studi Teknologi Pangan Unsrat, \\ ${ }^{2)}$ Dosen Program Studi Teknologi Pangan Unsrat \\ *e-mail: putrisachlan@gmail.com
}

\begin{abstract}
The aims of this reaserch are to determine the right combination of glucose syrup and gelatin, to analyze the physical and chemical components and to evaluate the preference level of the panelists in kuini mango jelly candy. This research has used factorials RAL method with 2 factors, which A factor is glucose syrup concentration and $\mathrm{B}$ factor is gelatin concentration. The result of the research found that $A_{3} B_{3}$ samples that contain $50 \%$ of glucose syrup and $25 \%$ of gelatin were the most preferred sample by panelist. In conclusion, mostly panelists prefer the sweetest and the hardest sample.
\end{abstract}

Keywords: kuini mango, glucose syrup, gelatine, jelly candy

\section{PENDAHULUAN}

Produksi mangga di Sulawesi Utara pada tahun 2017 sebanyak 6.619 ton (Badan Pusat Statistik Indonesia, 2018). Salah satu jenis mangga yang disukai oleh masyarakat adalah mangga kuini (Mangifera odorata Griff). Mangga kuini merupakan jenis mangga yang memiliki nilai jual rendah pada saat panen raya dan memiliki masa simpan yang singkat.

Mangga kuini masak mempunyai tekstur lunak berair dan berwarna kuning serta berserat dengan rasa yang manis dan asam. Mangga kuini dapat dibedakan dari jenis mangga lainnya dari aromanya yang khas, aroma khas tersebut disebabkan oleh komponen-komponen volatil yang terdapat pada kulit dan dagingmya. Rasa dan aroma khas dari mangga kuini dapat digunakan untuk memberikan flavor alami pada produk olahan pangan. Salah satu upaya untuk memanfaatkan flavor alami dan memperpanjang masa simpan adalah dengan mengolah mangga kuini menjadi produk olahan permen.

Permen merupakan salah satu produk pangan yang digemari hampir semua kalangan karena mudah untuk dikonsumsi. Permen mempunyai berbagai jenis seperti permen keras, marshmellow, permen jelly dan lain-lain. Permen jelly adalahpermen bertekstur lunak yang diproses dengan penambahan komponen hidrokoloid seperti agar, gum pektin, pati, karagenan, gelatin dan lain-lain yang digunakan untuk memodifikasi tekstur sehingga menghasilkan produk yang kenyal dan harus dicetak (SNI 3547.2- 
2008). Bahan utama pembuatan permen jelly adalah air, gelatin, pemanis (sukrosa dan sirup glukosa), flavor, dan pewarna. Selain bahan utama terdapat bahan tambahan yang digunakan yaitu asam sitrat sebagai penegas rasa (Turing dkk, 2007), serta tepung tapioka dan gula halus sebagai bahan pelapis (Koswara, 2009).

Sirup glukosa merupakan salah satu bahan utama pada pembuatan permen. Sirup glukosa dalam pembuatan permen jelly berfungsi mencegah terjadinya kristalisasi yang dapat merusak tekstur permen jelly, membangun struktur dan mempertahankan struktur dari permen jelly (Turing dkk, 2007). Jika sirup glukosa yang digunakan terlalu banyak, maka akan menghasilkan permen yang mempunyai tekstur yang terlalu liat, sedangkan jika sirup glukosa yang digunakan terlalu sedikit, maka permen yang dihasilkan akan mempunyai tekstur yang mudah putus (Faridah dkk, 2008).

Penambahan gelling agent pada pembuatan permen jelly sangat penting karena bertujuan membentuk tekstur kenyal dan empuk, salah satu gelling agent yang diigunakan adalah gelatin. Faktor penting dalam pembuatan permen jelly adalah konsentrasi gelatin. Jika konsentrasi gelatin terlalu sedikit, maka tidak akan terbentuk gel, tetapi bila konsentrasi gelatin yang digunakan terlalu banyak maka akan terbentuk tekstur yang kaku.

Berdasarkan uraian di atas, maka penelitian ini dilakukan untuk menentukan kombinasi sirup glukosa dan gelatin yang tepat pada pembuatan permen jelly mangga kuini.

\section{METODE PENELITIAN}

Penelitian ini dilaksanakan di Laboratorium Ilmu dan Teknologi Pangan dan Laboratorium Uji Teknologi Pangan dan Hasil Pertanian, Jurusan Teknologi Pertanian Fakultas Pertanian, Universitas Sam Ratulangi Manado (UNSRAT) dan
Laboratorium Balai Riset dan Standarisasi Industri Manado. Penelitian dilakukan dalam jangka waktu 5 bulan.

Bahan-bahan yang digunakan dalam penelitian ini antara lain: Mangga kuini masak, sirup glukosa, sukrosa, gelatin sapi, asam sitrat dan aquades.

Alat-alat yang digunakan, antara lain: Timbangan analitik, blender, saringan, gelas ukur, termometer dan cetakan.

Penelitian ini menggunakan metode percobaan yang disusun dalam Rancangan Acak Lengkap (RAL) faktorial dengan 2 faktor dan setiap perlakuan dilakukan 3 kali pengulangan (Tabel 3). Faktor A adalah konsentrasi sirup glukosa dan faktor B adalah konsentrasi gelatin:

Faktor A: (Konsentrasi Sirup Glukosa): $\mathrm{A}_{1}=30 \%, \mathrm{~A}_{2}=40 \%, \mathrm{~A}_{3}=50 \%$

Faktor B: (Konsentrasi Gelatin):

$\mathrm{B}_{1}=15 \%, \mathrm{~B}_{2}=20 \%, \mathrm{~B}_{3}=25 \%$

\section{Prosedur Kerja}

\section{Pembuatan Sari Mangga Kuini}

Mangga kuini dibersihkan pada air yang mengalir, selanjutnya dikupas. Daging mangga kuini selanjutnya dipotong-potong dan di-blanching selama 3 menit. Daging mangga yang telah diblanching didinginkan dan diblender. Mangga yang telah di-blender kemudian disaring sehingga sari terpisah dari seratnya.

\section{Pembuatan Permen Jelly Mangga Kuini}

Sari mangga kuini sebanyak 100 $\mathrm{mL}$ dimasukkan bersamaan dengan sukrosa 25 gr dan sirup glukosa sesuai dengan perlakuan (30gr, 40 gr dan 50 gr) kemudian dipanaskan sambil dilakukan pengadukan selama pemasakan. Larutkan gelatin (15 gr, 20 gr dan 25 gr) pada air hangat $\left(50^{\circ} \mathrm{C}\right)$ sebanyak $50 \mathrm{~mL}$ di wadah yang berbeda. Setelah gula larut, tambahkan gelatin yang telah dilarutkan. Pemanasan kembali dilanjutkan sampai suhu $80^{\circ} \mathrm{C}$ selama 5 menit sampai kental dan diangkat. Selanjutnya larutan permen 
dituangkan ke dalam cetakan ukuran $10 \mathrm{x}$ $15 \mathrm{~cm}$ dengan ketebalan $2 \mathrm{~cm}$ dan diamkan pada suhu ruang selama 1 jam. Setelah 1 jam, permen jelly dimasukkan ke dalam lemari pendingin selama 24 Jam. Setelah dikeluarkan dari lemari pendingin, permen jelly didiamkan pada suhu ruangan selama 1 jam, dipotong kotakkotak dan dilapisi dengan bahan pelapis.

\section{Variabel Pengamatan}

Permen Jelly yang dihasilkan diuji sifat kimia, yaitu kadar air metode oven, kadar abu metode gravimetri dan gula reduksi metode Luff Schoorl. Diuji sifat organoleptik dengan metode hedonik.

\section{Prosedur Analisis}

\section{Uji Organoleptik Metode Hedonik}

Uji kesukaan atau uji penerimaan disebut uji hedonik. Dalam pengujian ini panelis diminta tanggapan pribadinya tentang kesukaan atau ketidaksukaan terhadap produk yang disajikan dengan menggunakan skala 1 (satu) sampai 5 (lima). Uji organoleptik dilakukan oleh 25 orang panelis dengan parameter yang diuji, yaitu rasa, warna, aroma, dan tekstur yang bertujuan untuk mengetahui respon panelis terhadap sifat-sifat produk yang disajikan dalam bentuk kuisioner. Penilaian diberikan berdasarkan 5 skala penilaian, yaitu: (1) Sangat tidak suka, (2) Tidak suka, (3) Netral, (4) Suka dan (5) Sangat suka.

\section{HASIL DAN PEMBAHASAN}

\section{Sifat organoleptik}

\section{Tingkat kesukaan terhadap warna}

Nilai rata-rata tingkat kesukaan warna berada pada 3,12-3,88 (netral-suka) (Tabel 6). Hasil pengujian sidik ragam menunjukkan bahwa perlakuan sirup glukosa serta interaksi sirup glukosa dan gelatin berpengaruh pada tingkat kesukaan warna. Uji BNT 5\% menunjukkan adanya perbedaan nyata dengan adanya perbedaan notasi.

Tabel 6. Nilai rata-rata tingkat kesukaan terhadap warna permen jelly

\begin{tabular}{ccc}
\hline \multicolumn{2}{c}{ Perlakuan } & Rata-rata \\
\hline & $\mathrm{B}_{1}(15 \%)$ & $3,80^{b}$ \\
$\mathrm{~A}_{1}(30 \%)$ & $\mathrm{B}_{2}(20 \%)$ & $3,12^{a}$ \\
& $\mathrm{~B}_{3}(25 \%)$ & $3,16^{a}$ \\
\hline \multirow{3}{*}{$\left.\mathrm{A}_{2}(40 \%)\right)$} & $\mathrm{B}_{1}(15 \%)$ & $3,20^{a b}$ \\
& $\mathrm{~B}_{2}(20 \%)$ & $3,84^{b}$ \\
& $\mathrm{~B}_{3}(25 \%)$ & $3,80^{b}$ \\
\hline & $\mathrm{B}_{1}(15 \%)$ & $3,80^{b}$ \\
$\mathrm{~A}_{3}(50 \%)$ & $\mathrm{B}_{2}(20 \%)$ & $3,88^{b}$ \\
& $\mathrm{~B}_{3}(25 \%)$ & $3,36^{a b}$ \\
\hline
\end{tabular}

BNT 5\% = 0,51 (*) Notasi yang berbeda menunjukkan adanya perbedaan nyata.

Warna menjadi faktor yang penting dalam penilaian organoleptik, karena warna dapat merupakan faktor pertama dalam penilaian suatu produk pangan. Menurut Rauf (2015), warna adalah salah satu atribut utama pangan yang menentukan penerimaan konsumen yang menunjukkan bahwa konsumen menghubungkan warna makanan dengan kualitas bahan pangan.

Warna dari permen jelly mangga kuini diduga dipengaruhi oleh mangga kuini dan kadar air. Pengaruh kadar air terhadap warna diduga jika semakin banyak air maka warna akan semakin memudar dan semakin berkurangnya air maka warna akan semakin pekat. Seperti penelitian Jong dan Seok (2011) yang melihat perubahan warna dari paprika merah seiring bertambahnya air dan menyatakan semakin banyak air yang ditambahkan, maka warna akan semakin memudar. Bertambah dan berkurangnya air dalam pembuatan permen jelly dipengaruhi oleh penambahan gelatin sebagai gelling agent yang mengikat air. Sehingga, semakin bertambah konsentrasi gelatin maka warna dari permen jelly akan semakin pekat. 


\section{Tingkat kesukaan terhadap aroma}

Nilai rata-rata tingkat kesukaan aroma permen jelly menunjukkan bahwa nilai rata-rata berada pada $3,12-3,84$ (Tabel 7).

Tabel 7. Nilai rata-rata tingkat kesukaan terhadap aroma permen jelly

\begin{tabular}{ccc}
\hline \multicolumn{2}{c}{ Perlakuan } & Rata-rata \\
\hline \multirow{3}{*}{$\mathrm{A}_{1}(30 \%)$} & $\mathrm{B}_{1}(15 \%)$ & 3,56 \\
& $\mathrm{~B}_{2}(20 \%)$ & 3,36 \\
& $\mathrm{~B}_{3}(25 \%)$ & 3,28 \\
\hline & $\mathrm{B}_{1}(15 \%)$ & 3,52 \\
$\mathrm{~A}_{2}(40 \%)$ & $\mathrm{B}_{2}(20 \%)$ & 3,12 \\
& $\mathrm{~B}_{3}(25 \%)$ & 3,68 \\
\hline & $\mathrm{B}_{1}(15 \%)$ & 3,72 \\
$\mathrm{~A}_{3}(50 \%)$ & $\mathrm{B}_{2}(20 \%)$ & 3,68 \\
& $\mathrm{~B}_{3}(25 \%)$ & 3,84 \\
\hline
\end{tabular}

Hasil pengujian sidik ragam menunjukkan bahwa perlakuan sirup glukosa berpengaruh terhadap tingkat kesukaan aroma permen jelly mangga kuini. Tetapi, setelah dilakukan uji BNT didapati tidak adanya perbedaan dari perlakuan sirup glukosa.

Aroma merupakan salah satu parameter yang menentukan lezat atau tidaknya suatu makanan. Aroma juga merupakan indikator penting dalam industri pangan karena dengan cepat dapat memberikan hasil penilaian yang diterima atau tidaknya produk tersebut (Susanti dan Titiek, 2014). Aroma pada produk permen jelly ini adalah aroma khas dari mangga kuini. Aroma khas dari mangga kuini disebabkan oleh komponen-komponen volatil yang menyusun flavor kuini. Menurut penelitian Wijaya, dkk (1997) terdapat 23 komponen volatile pada kulit dan daging mangga kuini dimana komponen ethyl butanoate dan ethyl crotonoate menjadi komponen yang paling dominan. Komponen volatil tersebut memberikan bau manis dan rasa pahit.

\section{Tingkat kesukaan terhadap rasa}

Nilai rata-rata tingkat kesukaan rasa permen jelly menunjukkan bahwa nilai rata-rata berada pada 2,56-3,64 (netralsuka) (Tabel 8).

Tabel 8. Nilai rata-rata tingkat kesukaan rasa permen jelly

\begin{tabular}{ccc}
\hline \multicolumn{2}{c}{ Perlakuan } & Rata-rata \\
\hline & $\mathrm{B}_{1}(15 \%)$ & $3,24^{b}$ \\
$\mathrm{~A}_{1}(30 \%)$ & $\mathrm{B}_{2}(20 \%)$ & $3,44^{b}$ \\
& $\mathrm{~B}_{3}(25 \%)$ & $3,00^{a b}$ \\
\hline \multirow{3}{*}{$\mathrm{A}_{2}(40 \%)$} & $\mathrm{B}_{1}(15 \%)$ & $2,88^{a b}$ \\
& $\mathrm{~B}_{2}(20 \%)$ & $2,56^{a}$ \\
& $\mathrm{~B}_{3}(25 \%)$ & $3,52^{b}$ \\
\hline \multirow{3}{*}{$\mathrm{A}_{3}(50 \%)$} & $\mathrm{B}_{1}(15 \%)$ & $3,28^{b}$ \\
& $\mathrm{~B}_{2}(20 \%)$ & $3,16^{b}$ \\
& $\mathrm{~B}_{3}(25 \%)$ & $3,64^{b}$ \\
\hline BNT 5\% =0,57 (*) Notasi yang berbeda menunjukkan \\
adanya perbedaan nyata.
\end{tabular}

Hasil pengujian sidik ragam menunjukkan bahwa interaksi sirup glukosa dan gelatin berpengaruh terhadap tingkat kesukaan rasa permen jelly mangga kuini. Uji BNT 5\% menunjukkan adanya perbedaan nyata dengan adanya perbedaan notasi.

Rasa merupakan respon dari indera perasa (lidah) terhadap rangsangan yang diberikan oleh suatu makanan yang merupkan salah satu faktor penting yang mempengaruhi tingkat penerimaan panelis terhadap suatu produk pangan (Susanty dan Titiek, 2014). Nilai rata-rata kesukaan rasa menunjukkan bahwa konsentrasi sirup glukosa dan gelatin dapat mempengaruhi tingkat kesukaan panelis terhadap permen jelly, dilihat dari perlakuan sirup glukosa $50 \%$ dan gelatin $25 \%$ menjadi perlakuan dengan nilai tingkat kesukaan tertinggi dan hal ini diduga karena rasa manis yang dipengaruhi oleh banyaknya konsentrasi sirup glukosa dan tekstur yang dipengaruhi oleh gelatin. Selain sirup glukosa dan gelatin, faktor lain yang mempengaruhi rasa dari permen jelly adalah sari mangga kuini yang 
memberikan rasa yang unik, penambahan asam sitrat dan sukrosa.

Tekstur dari permen jelly diduga berpengaruh terhadap rasa dari permen jelly karena tekstur dari permen jelly yang dihasilkan agak lunak sehingga diduga panelis membandingkan tekstur permen jelly mangga kuini dengan permen jelly komersial. Scott-Thomas (2011) menyatakan bahwa menurut Research Chefs Association, tekstur dapat mempengaruhi presepsi orang tentang makanan. Winarno (2011) juga menyatakan jika tekstur dari suatu bahan akan mempengaruhi cita rasa yang ditimbulkan oleh bahan tersebut, sesuai dengan penelitian Katsunori dan Spence (2011) yang menyatakan bahwa tekstur dari makanan mempengaruhi rasa serta penampilan dari makanan.

\section{Tingkat kesukaan terhadap tekstur}

Nilai rata-rata tingkat kesukaan tekstur permen jelly menunjukkan nilai rata-rata berada pada 2,36-3,76 (tidak suka-suka) (Tabel 9).

Tabel 9. Nilai rata-rata tingkat kesukaan tekstur permen jelly

\begin{tabular}{ccc}
\hline \multicolumn{2}{c}{ Perlakuan } & Rata-rata \\
\hline & $\mathrm{B}_{1}(15 \%)$ & $2,56^{a b}$ \\
$\mathrm{~A}_{1}(30 \%)$ & $\mathrm{B}_{2}(20 \%)$ & $3,96^{c}$ \\
& $\mathrm{~B}_{3}(25 \%)$ & $3,76^{c}$ \\
\hline & $\mathrm{B}_{1}(15 \%)$ & $3,20^{b}$ \\
$\mathrm{~A}_{2}(40 \%)$ & $\mathrm{B}_{2}(20 \%)$ & $3,28^{b}$ \\
& $\mathrm{~B}_{3}(25 \%)$ & $3,72^{c}$ \\
\hline & $\mathrm{B}_{1}(15 \%)$ & $2,36^{a}$ \\
$\mathrm{~A}_{3}(50 \%)$ & $\mathrm{B}_{2}(20 \%)$ & $2,96^{b}$ \\
& $\mathrm{~B}_{3}(25 \%)$ & $3,76^{c}$ \\
\hline
\end{tabular}

BNT 5\% $=0,60(*)$ Notasi yang berbeda.menunjukkan adanya perbedaan nyata

Hasil pengujian sidik ragam menunjukkan bahwa perlakuan sirup glukosa, perlakuan gelatin, serta interaksi sirup glukosa dan gelatin berpengaruh pada tingkat kesukaan tekstur permen jelly mangga kuini. Tetapi, hanya pengujian
BNT interaksi sirup glukosa-gelatin yang dibahas karena telah mewakili kedua perlakuan (Tabel 9). Uji BNT 5\% menunjukkan adanya perbedaan nyata dengan adanya perbedaan notasi.

Tekstur adalah penampakan secara umum yang menjadi pertimbangan dalam penerimaan suatu produk. Hasil statistik menunjukkan bahwa semakin meningkatnya konsentrasi sirup glukosa dan gelatin, maka nilai kesukaan panelis terhadap tekstur permen jelly mangga kuini semakin meningkat. Hal ini diduga berhubungan dengan rasa manis dari sirup glukosa dan kekuatan gel yang terbentuk yang dipengaruhi oleh konsentrasi gelatin yang ditambahkan. Sesuai dengan Rauf (2015), gelatin menyerap air dengan kapasitas tinggi, sehingga memberikan karakteristik khas pada produk pangan khususnya dalam pembentukan gel dengan meningkatkan viskositas.

Tekstur permen jelly selain berhubungan dengan rasa dan kekuatan gel, juga berhubungan dengan kadar air dari permen jelly. Tekstur permen jelly yang agak lunak diduga karena kadar air yang tinggi dan disebabkan oleh suhu pemasakan yang rendah $\left(80^{\circ} \mathrm{C}\right)$. Disebabkan oleh tekstur yang lunak karena kadar air yang tinggi, maka mempengaruhi presepsi panelis terhadap rasa dan penampilan permen jelly seperti dalam Scott-Thomas (2011) menyatakan bahwa menurut Research Chefs Association, tekstur dapat mempengaruhi presepsi orang tentang makanan, sesuai dengan penelitian Katsunori dan Spence (2011) yang menyatakan bahwa tekstur dari makanan mempengaruhi rasa serta penampilan dari makanan.

\section{KESIMPULAN}

Uji tingkat kesukaan warna, aroma, rasa dan tekstur dari permen jelly mangga kuini berada pada range netral. Permen jelly dengan konsentrasi sirup glukosa $50 \%$ dan gelatin $25 \%$ memiliki 
tingkat kesukaan yang paling tinggi pada atribut rasa dan aroma. Konsentrasi sirup glukosa $30 \%$ dan gelatin $20 \%$ memiliki tingkat kesukaan yang paling tinggi pada atribut tekstur. Konsentrasi sirup glukosa $50 \%$ dan gelatin $20 \%$ memiliki tingkat kesukaan yang paling tinggi pada atribut warna.

\section{DAFTAR PUSTAKA}

Brown, A. 2011. Understanding Food: Principles and Preparation, Fourth Edition. United State of America: Wadsworth Cengage Learning.

Chen, C., Li. W., Yong. C. S., Lin. D. W dan Ning, Z. 2012. Formation of Water and Glucose Clusters by Hydrogen Bonds in Glucose Aqueous Solutions. Computational and Theoretical Chemistry 984 (2012) 85-92.

Edwards, W. P. 2000. The Science of Sugar Confectionery. United Kingdom: Royal Society of Chemistry.

Jong, W. R. dan I. H. Seok. Effect of Water Activity and Temperature on the Color Change of Red Pepper (Capsicum annum L.) Powder. 2011. Food Science and Biotechnology 20(1): 215-222.

Katsunori, O. dan C. Spence. 2011. Effects of Visual Food Texture on Taste Preception. i-Perception (2011) volume 3, pages 966.

Koswara, S. 2009. Teknologi Pembuatan Permen. Ebookpangan.com http//tekpan.unimus.ac.id/wpconte nt/uploads/2013/07/TEKNOLOGIPEMBUATAN-PERMEN.pdf Diakses 5 Juni 2018.

Nelwan, B., T. Langi., T. Koapaha dan T. Tuju. 2015. Pengaruh Konsentrasi Gelatin dan Sirup Glukosa terhadap Sifat Kimia dan Sensoris Permen Jelly Sari Buah Pala (Myristica fragrans Houtt). Cocos: Vol 6, No 3 (2015).
Rauf, R. 2015. Kimia Pangan. Yogyakarta: Penerbit ANDI.

Rifai, M. 2013. Identifikasi Pencirian Fisikokimia Gelatin dari Tulang Sapi dan Babi. Skripsi. Fakultas Matematika dan Ilmu Pengetahuan Alam: Institut Pertanian Bogor. Bogor.

Scott-Thomas, C. 2011. The Impact of Texture on Taste Perception. https://www.foodnavigatorusa.com/Article/2011/03/08/Theimpact-of-texture-on-tasteperception. Di akses 16 Juni 2019.

Sumarmono, J. 2012. Pengukuran Keempukan Daging dengan Penetrometer.

http://panganhewani.blog.unsoed.a c.id/files/2012/05/Pengukuran-

Keempukan-Daging-denganPenetrometer.pdf. Diakses 14 Februari 2019

Talbot, G. 2009. Science and Technology of Enrobed and Filled Chocolate, Confectionery and Bakery Products. United Kingdom: Woodhead Publishing Limited.

Turing, A. M., J. van Fraunhofer dan C. Abbe. 2007. How Products Are Made Volume 3: Gummy Candy. https://madehow.com/Volume3/Gummy-Candy.html. Di akses 14 Februari 2019.

Wijaya, C. H., H. Raharja dan A. Apriyantono. 1997. Identifikasi dan Karakterisasi Potent Odorant Mangga Kweni (Mangifera odorata Griff). Hasil Penelitian. Buletin Teknologi dan Industri Pangan, Vol VIII, No. 2, Tahun 1997.

Winarno, F. G. 1991. Kimia Pangan dan Gizi. Jakarta: PT Gramedia Pustaka Utama. 